\title{
Prevalence of testing and coronavirus-19 among nurses in the pandemic
}

\author{
Prevalência de testagem e coronavírus-19 entre enfermeiros na pandemia \\ Prevalencia de pruebas y coronavirus-19 entre enfermeros en la pandemia
}

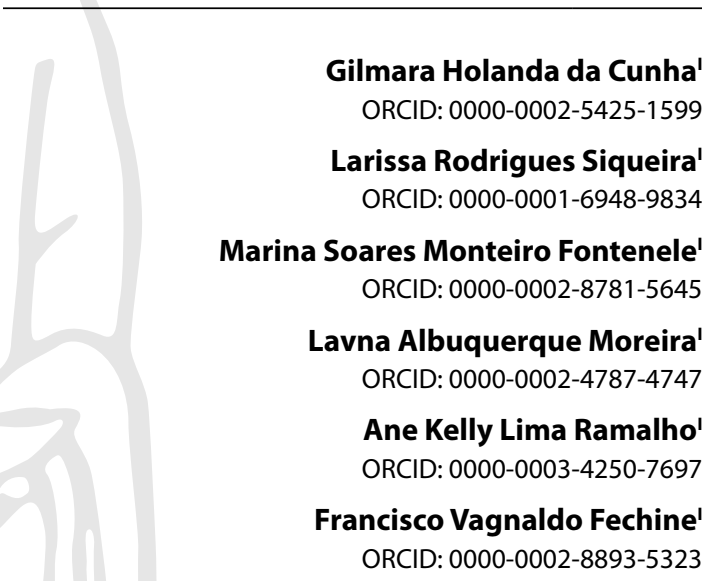

'Universidade Federal do Ceará. Fortaleza, Ceará, Brazil.

How to cite this article:

Cunha GH, Siqueira LR, Fontenele MSM, Moreira LA

Ramalho AK, Fechine FV. Prevalence of testing and coronavirus-19 among nurses in the pandemic Rev Bras Enferm. 2022;75(Suppl 1):e20210365. https://doi.org/10.1590/0034-7167-2021-0365

Corresponding author:

Gilmara Holanda da Cunha

E-mail: gilmaraholandaufc@yahoo.com.br

EDITOR IN CHIEF: Dulce Barbosa ASSOCIATE EDITOR: Mitzy Danski

Submission: 05-25-2021

Approval: $12-07-2021$

\begin{abstract}
Objective: To determine the prevalence of testing and COVID-19 among nurses during the pandemic in the State of Ceará. Method: A cross-sectional study with 379 nurses, through a network sampling technique, using a sociodemographic, labor, and clinical questionnaire. The study performed a descriptive statistics, univariate and multivariate logistic regression analysis. Results: The prevalence of testing and COVID-19 were, respectively, $63.3 \%$ and $25.0 \%$. The most common symptoms were anosmia, ageusia, and myalgia. There was inadequate use of personal protective equipment due to material shortage. The odds ratio for COVID-19 was higher in those with children, people with diabetes, from the capital, with more than two jobs, in hospital and emergency room, and from the frontline. In the multivariate logistic regression, nurses with children $(p=0.011)$, diabetics $(p=0.018)$ and frontline $(p<0.001)$ had more chances for COVID-19. Conclusion: Expanded testing, ongoing in-service education, and adequate personal protective equipment are needed to improve nurses' work. Descriptors: Coronavirus Infections; COVID-19; Nursing; Prevalence; Pandemics.
\end{abstract}

\section{RESUMO}

Objetivo: Determinar a prevalência de testagem e COVID-19 entre enfermeiros, durante a pandemia no estado do Ceará. Método: Estudo transversal com 379 enfermeiros, com técnica de amostragem em rede, utilizando-se questionário sociodemográfico, laboral e clínico. Realizou-se estatística descritiva, análise de regressão logística univariada e multivariada. Resultados: A prevalência de testagem e COVID-19 foram, respectivamente, $63,3 \%$ e $25,0 \%$. Sintomas mais comuns foram anosmia, ageusia e mialgia. Referiu-se uso inadequado de equipamentos de proteção individual por escassez de material. A razão de chances para COVID-19 foi maior naqueles com filhos, diabéticos, da capital, com mais de dois empregos, em hospital e pronto atendimento e da linha de frente. Na regressão logística multivariada, tiveram mais chances para COVID-19, os enfermeiros com filhos ( $p=0,011)$, diabéticos $(p=0,018)$ e da linha de frente $(p<0,001)$. Conclusões: Ampliação da testagem, educação permanente em serviço e equipamentos de proteção individual adequados são necessários para melhorar o trabalho dos enfermeiros.

Descritores: Infecções por Coronavírus; COVID-19; Enfermagem; Prevalência; Pandemias.

\section{RESUMEN}

Objetivo: Determinar prevalencia de testeo y COVID-19 entre enfermeros, durante la pandemia en el estado de Ceará. Método: Estudio transversal con 379 enfermeros, con técnica de muestreo por redes, utilizándose encuesta sociodemográfica, laboral y clínica. Realizada estadística descriptiva, análisis de regresión logística simple y múltiple. Resultados: La prevalencia de testeo y COVID-19 fueron, respectivamente, $63,3 \%$ y $25,0 \%$. Síntomas más comunes fueron anosmia, ageusia y mialgia. Referido uso inadecuado de equipos de protección individual por escasez de material. La razón de probabilidades para COVID-19 fue mayor en aquellos con hijos, diabéticos, de la capital, con más de dos empleos, en hospital y servicios médicos de urgencia y de primera línea. La regresión logística múltiple, tuvieron más probabilidades para COVID-19, enfermeros con hijos $(p=0,011)$, diabéticos $(p=0,018)$ y de primera línea $(p<0,001)$. Conclusiones: Ampliación de testeo, educación permanente en servicio y equipos de protección individual adecuados son necesarios para optimización laboral de enfermeros.

Descriptores: Infecciones por Coronavirus; COVID-19; Enfermería; Prevalencia; Pandemias. 
Prevalence of testing and coronavirus-19 among nurses in the pandemic Cunha GH, Siqueira LR, Fontenele MSM, Moreira LA, Ramalho AK, Fechine FV.

\section{INTRODUCTION}

The COVID-19 pandemic has led to a global economic slowdown, the collapse of the health system in some countries, and has negatively interfered with people's physical and mental health ${ }^{(1)}$. In January 2021, Brazil was the third country in the world in the number of COVID-19 cases $(8,075,998)$, behind only India $(10,450,284)$ and the United States of America $(22,192,842)^{(2)}$. So far, 345,211 cases and 10,237 deaths were confirmed in the state of Ceará(3).

The pandemic has restructured public and private health services. Elective consultations, examinations, and non-emergency procedures gave way to the care of patients with COVID-19, changing the regular health follow-up of others and the work routine of health professionals ${ }^{(4)}$. In this critical situation, health professionals are the ones who have the most contact with $\mathrm{CO}$ VID-19 patients, as they are involved in diagnosis, treatment, and rehabilitation. Nurses have high exposure to the virus because their work involves direct care to patients, and specific protocols are needed in health institutions to reduce the risk of infection during interactions with patients ${ }^{(5)}$.

In addition, there is a high workload, lack of personal protective equipment (PPE), and specific medications, in addition to the feeling of inadequate support that can contribute to the mental burden of health professionals. These individuals fear the infection of family members, feel uncertainty, and suffer stigmatization, with reports of stress, anxiety, depression, burnout, addiction, and post-traumatic stress disorder, which may have long-term psychological implications ${ }^{(6-8)}$.

For nurses working in intensive care in the COVID-19 pandemic, the main stressors are anxiety regarding work environments and processes, lack of experience with infectious diseases, concern about being infected, high workload, fatigue, and depression due to the unsuccessful cure of critical patients, in addition to the concern for their families ${ }^{(7)}$. Nurses also need to wear a set of protective clothing, keeping their breathing limited to some extent. When dressed up, they do not drink water or go to the toilet, making the work difficult. The longer the weekly working time, the greater the physical and mental consumption, which may interfere with self-care ${ }^{(8)}$.

Some vaccines against COVID-19 were authorized in December 2020 for emergency use in many countries, starting in Brazil in January 2021 for health professionals and subsequently for other priority groups and the general population. Although vaccines can help put an end to the pandemic, they will not solve everything quickly since, as the COVID-19 crisis continues, protective measures are still needed to prevent the proliferation of the virus and its variants ${ }^{(2,4,8)}$.

Nurses are exposed to the new coronavirus (SARS-CoV-2) within health institutions by providing direct and continuous care to patients. Therefore, the follow-up of these professionals should also take place in their workplaces through testing, appropriate use of quality PPE, infection control practices, and updated conduct and psychological support ${ }^{(5-8)}$. Therefore, this study is proposed due to changes and the negative impact of the COVID-19 pandemic on the health system in Brazil and worldwide, as well as changes in the work dynamics of nurses, who work for long periods exposed to the virus and have work overload.

\section{OBJECTIVE}

To determine the prevalence of testing for SARS-CoV-2 and COVID-19 among nurses during the pandemic in the state of Ceará.

\section{METHODS}

\section{Ethical aspects}

The study was conducted under Resolution 466/2012 of the National Health Council. It followed the preservation, protection, and safety measures for research participants in virtual environments of the National Research Ethics Committee. All nurses signed the Informed Consent Form. The Research Ethics Committee of the Federal University of Ceará approved the project.

\section{Design, period and place of study}

This is a cross-sectional study conducted in the State of Ceará, Brazil, from June to December 2020. The research took place according to the guidelines for observational studies: Strengthening the Reporting of Observational Studies in Epidemiology (STROBE) ${ }^{(9)}$.

\section{Population or sample; criteria of inclusion and exclusion}

The sample should estimate the prevalence of nurses with COVID-19, having 95\% confidence that the estimation error did not exceed $5 \%$, considering that such prevalence was unknown in the population (stipulated at 50\% for providing a larger sample size) and that in the state of Ceará had 22,992 nurses registered with the regional Nursing Council in May ${ }^{(10)}$. Thus, the study applied the expression:

$$
n=\frac{z^{2} \cdot p \cdot(1-p) \cdot N}{\varepsilon^{2} \cdot(N-1)+z^{2} \cdot p \cdot(1-p)} .
$$

In this formula, $z^{2}$ is equal to the value of the statistic $z$ (1.96) for the degree of confidence adopted (95\%), and $p, N$, and $\varepsilon$ they correspond to the presumed prevalence $(0.50)$, population $(22,992)$, and tolerable error (0.05), respectively. The survey calculated a sample of 379 nurses. The research adopted the technique of non-probability network sampling, in which individuals selected nominate others to participate. It is used for samples that may be difficult to access otherwise and was very useful given the social isolation and restricted access to health services in the pandemic of COVID-19. Inclusion criteria: nurses of both sexes, with registration in the regional Nursing Council of Ceará and access to the internet, computer, or smartphone. Exclusion criteria: work outside the state of Ceará.

\section{Study protocol}

The research invited nurses to participate by email and WhatsApp application. The message sent contained research link, study description, ethics committee approval, consent form, and questionnaire on the Google platform.

The sociodemographic, labor, and clinical questionnaire contained the variables: age, sex, marital status, number of children and people at home, chronic disease, training time, occupational 
situation, the city where they worked, employment relationship, place, and sector of work, use of PPE, care for patients with COVID-19, test for SARS-CoV-2, result and symptoms. The average participation time ranged from 10 to 20 minutes. Before the study, 30 nurses that did not compose the sample responded to the research link and questionnaire for pilot test and validation.

\section{Analysis of results and statistics}

The study calculated the mean, standard deviation (SD), absolute and relative frequency. A univariate logistic regression analysis evaluated the association between variables and the occurrence of COVID-19-according to RT-PCR (Reverse Transcription-Polymerase Chain Reaction) and serology for SARS-CoV-2 (Severe Acute Respiratory Syndrome Coronavirus 2) tests results. The strength of association was measured by the odds ratio, accuracy ( $95 \%$ confidence interval), and significance of the estimate (Wald test). Explanatory variables related to the occurrence of COVID-19, with a significance level of $10 \%(p<0.10)$, were selected for multivariate logistic regression to identify those associated with the evaluated outcome.

The study used the step-by-step method stepwise and backward, as it was a criterion for removing variables from the model defined by the Wald test. Such analysis determined the adjusted odds ratio, accuracy (95\% confidence interval), and significance of the estimate (Wald test). Two-tailed tests were used, with a significance level of 0.05 (5\%), considered statistically significant $p<0.05$. It used the IBM SPSS Statistics v. 23.0 software.

\section{RESULTS}

The mean age of the 379 nurses was 36 years (SD: \pm 9.3 ), and most were less than 45 years old $(314 ; 82.8 \%)$. As for the performance, 262 (69.1\%) worked in the State capital, $103(27.1 \%)$ in the countryside, 14 (3.6\%) were unemployed, and 333 (87.8\%) had graduate degrees. Eighty-one nurses reported inadequate use of PPE (21.4\%), which occurred due to insufficient supply in the service or poor quality. See Table 1.

Of the 379 nurses, 240 were tested for COVID-19, and 95 were positive, with testing and COVID-19 prevalence in the sample, respectively, $63.3 \%$ and $25.0 \%$. Most performed serological tests for analysis of $\operatorname{lgM}$ and $\lg \mathrm{G}$ antibodies. See Table 2.

Among the 95 nurses with positive testing for SARS-CoV-2, only 93 showed signs and symptoms. The others $(n=147)$ went under testing without symptoms because they were in contact with people with COVID-19 or by the practice of testing health professionals at work. Table 3 shows the signs and symptoms of the nurses.

In the univariate logistic regression analysis, nurses with children were 1.9 times more likely ( $p=0.018)$ to have COVID-19 than those without children. People with diabetes were 5.74 times more likely $(p=0.032)$ than non-diabetics; capital workers were 1.64 times more likely $(p=0.098)$ than those from inland regions; those with two or more jobs were 1.68 times more likely $(p=0.053)$ than those with one job. Hospital or emergency room nurses were 1.66 times more likely $(p=0.059)$ than those in Primary Care; nursing, intensive care, or emergency workers were 1.67 times more likely $(p=0.058)$ than those in primary care. Those who provided direct care to patients with COVID-19 were 4.52 times more likely $(p=0.001)$ than those not active on the frontline of the fight against the pandemic. Among the nurses who took the test, four were unemployed and did not participate in the univariate analysis $(n=236)$. See Table 4.

Table 1 - Sociodemographic, labor, and clinical characterization of nurses during the COVID-19 pandemic, Fortaleza, Ceará, Brazil, 2020 ( $N=379)$

\begin{tabular}{|c|c|c|}
\hline Variables & $\mathbf{n}$ & $\%$ \\
\hline \multicolumn{3}{|l|}{ Sex } \\
\hline Male & 48 & 12.6 \\
\hline Female & 331 & 87.4 \\
\hline \multicolumn{3}{|l|}{ Marital status } \\
\hline No partner (single, separated, widowed) & 170 & 44.8 \\
\hline Married/stable union & 209 & 55.2 \\
\hline \multicolumn{3}{|l|}{ Children } \\
\hline Yes & 193 & 51.0 \\
\hline No & 186 & 49.0 \\
\hline \multicolumn{3}{|l|}{ Number of persons in the household } \\
\hline$\leq 3$ persons & 244 & 64.4 \\
\hline$>3$ people & 135 & 35.6 \\
\hline \multicolumn{3}{|l|}{ Systemic arterial hypertension } \\
\hline Yes & 32 & 8.5 \\
\hline No & 347 & 91.5 \\
\hline \multicolumn{3}{|l|}{ Diabetes mellitus } \\
\hline Yes & 12 & 3.2 \\
\hline No & 367 & 96.8 \\
\hline \multicolumn{3}{|l|}{ Graduation time } \\
\hline$\leq 10$ years & 238 & 62.8 \\
\hline$>10$ years & 141 & 37.2 \\
\hline \multicolumn{3}{|l|}{ Occupational situation } \\
\hline Assets & 365 & 96.4 \\
\hline Unemployed & 14 & 3.6 \\
\hline \multicolumn{3}{|l|}{ Employment links } \\
\hline$\geq 2$ jobs & 134 & 35.5 \\
\hline 1 job & 231 & 60.9 \\
\hline Unemployed & 14 & 3.6 \\
\hline \multicolumn{3}{|l|}{ Workplace } \\
\hline Hospital/emergency unit & 177 & 46.7 \\
\hline Basic health unit & 188 & 49.7 \\
\hline Unemployed & 14 & 3.6 \\
\hline \multicolumn{3}{|l|}{ Sector of work } \\
\hline Infirmary/intensive care/emergency & 173 & 45.6 \\
\hline Primary Care & 192 & 50.8 \\
\hline Unemployed & 14 & 3.6 \\
\hline \multicolumn{3}{|l|}{ Proper use of personal protective equipment } \\
\hline Yes & 284 & 75.0 \\
\hline No & 81 & 21.4 \\
\hline Unemployed & 14 & 3.6 \\
\hline \multicolumn{3}{|l|}{ Care for patients with COVID-19 } \\
\hline Yes & 253 & 66.8 \\
\hline No & 112 & 29.6 \\
\hline Unemployed & 14 & 3.6 \\
\hline
\end{tabular}

Table 2 - SARS-CoV-2 test results of nurses in the pandemic. Data expressed as absolute and relative frequency, Fortaleza, Ceará, Brazil, 2020 ( N = 379)

\begin{tabular}{lcc}
\hline Variables & $\mathbf{n}$ & $\%$ \\
\hline SARS-CoV-2 test results & & \\
$\quad$ Positive & 95 & 25.0 \\
Negative & 145 & 38.4 \\
Did not go under test & 139 & 36.6 \\
Test type for SARS-CoV-2 & & \\
RT-PCR & 76 & 20.0 \\
Serology & 164 & 43.4 \\
Did not go under test & 139 & 36.6 \\
\hline
\end{tabular}

SARS-CoV-2 - Severe Acute Respiratory Syndrome Coronavirus; RT-PCR - Reverse Transcription Polymerase Chain Reaction. 
Table 3 - Signs and symptoms of nurses who tested positive for SARS-CoV-2, Fortaleza, Ceará, Brazil, 2020

\begin{tabular}{|c|c|c|}
\hline Signs and symptoms & $\mathbf{n}$ & $\%$ \\
\hline \multicolumn{3}{|l|}{ Fever } \\
\hline Yes & 45 & 48.4 \\
\hline No & 48 & 51.6 \\
\hline \multicolumn{3}{|l|}{ Cough } \\
\hline Yes & 56 & 60.3 \\
\hline No & 37 & 39.7 \\
\hline \multicolumn{3}{|l|}{ Coryza } \\
\hline Yes & 56 & 60.3 \\
\hline No & 37 & 39.7 \\
\hline \multicolumn{3}{|l|}{ Anosmia } \\
\hline Yes & 62 & 66.7 \\
\hline No & 31 & 33.3 \\
\hline \multicolumn{3}{|l|}{ Ageusia } \\
\hline Yes & 59 & 63.5 \\
\hline No & 34 & 36.5 \\
\hline \multicolumn{3}{|l|}{ Dyspnea } \\
\hline Yes & 29 & 31.2 \\
\hline No & 64 & 68.8 \\
\hline \multicolumn{3}{|l|}{ Chest pain } \\
\hline Yes & 34 & 36.6 \\
\hline No & 59 & 63.4 \\
\hline \multicolumn{3}{|l|}{ Myalgia } \\
\hline Yes & 71 & 76.4 \\
\hline No & 22 & 23.6 \\
\hline \multicolumn{3}{|l|}{ Adynamia } \\
\hline Yes & 72 & 77.5 \\
\hline No & 21 & 22.5 \\
\hline \multicolumn{3}{|l|}{ Diarrhea } \\
\hline Yes & 44 & 47.4 \\
\hline No & 49 & 52.6 \\
\hline
\end{tabular}

The study selected the variables that had significance in the univariate analysis, according to Wald test, less than $0.10(p<0.10)$ for multivariate logistic regression. Just having children, diabetes mellitus, and providing direct care to patients with COVID-19 were independent factors associated with COVID-19 in nurses. People who had children were 2.12 times more likely than those without children. People with diabetes were 8.61 times more likely than non-diabetic people, but with a broad confidence interval due to the low frequency of this condition in the cohort studied. Frontline nurses were 5.71 times more likely than others (Table 5).

\section{DISCUSSION}

Most of the nurses in the study were female, under 45 years of age, with 36 years being the average age, agreeing with other research that evaluated health professionals in the COVID-19 pandemic ${ }^{(11-13)}$. Regarding age, this can occur because people with comorbidities and the elderly have more risks for complications and mortality from the new coronavirus ${ }^{(11)}$; and, in some health services, these individuals are removed from usual activities and redirected to other functions ${ }^{(14)}$.

As for the occupational situation, the majority were employed, working in primary, secondary and tertiary care - health workers active in the direct care of patients with COVID-19 are called "frontline professionals" and are more exposed to infection ${ }^{(13)}$. Most had a post-graduate degree, emphasizing the importance of progress for the labor market. However, in the context of COVID-19, research has shown that, although most professionals know the transmission of infectious diseases and safe work practices, there are still deficits in the subject, mainly because it is a new disease, with daily scientific discoveries ${ }^{(15)}$.

Table 4 - Univariate logistic regression for the association between sociodemographic, labor and clinical variables of nurses and occurrence of COVID-19, by detection of SARS-CoV-2 by RT-PCR or serology, Fortaleza, Ceará, Brazil, 2020

\begin{tabular}{|c|c|c|c|c|c|c|c|}
\hline \multirow{3}{*}{ Variables } & \multicolumn{4}{|c|}{ Test for SARS-CoV-2 } & \multirow{3}{*}{ Odds ratio } & \multirow{3}{*}{$\begin{array}{c}\text { Confidence } \\
\text { interval } \\
95 \%\end{array}$} & \multirow{3}{*}{$\begin{array}{c}p \text { value } \\
\text { (Wald test) }\end{array}$} \\
\hline & \multicolumn{2}{|c|}{ Positive } & \multicolumn{2}{|c|}{ Negative } & & & \\
\hline & $\mathbf{n}$ & $\%$ & $\mathbf{n}$ & $\%$ & & & \\
\hline \multicolumn{8}{|l|}{ Sex } \\
\hline Female & 78 & 37.8 & 128 & 62.1 & 0.61 & $0.28-1.31$ & 0.207 \\
\hline Male & 15 & 50.0 & 15 & 50.0 & 1 & & \\
\hline \multicolumn{8}{|l|}{ Age } \\
\hline$>45$ years & 16 & 41.0 & 23 & 58.9 & 1.08 & $0.54-2.18$ & 0.821 \\
\hline$\leq 45$ years & 77 & 39.0 & 120 & 60.9 & 1 & & \\
\hline \multicolumn{8}{|l|}{ Marital status } \\
\hline No partner & 35 & 34.3 & 67 & 65.6 & 0.68 & $0.40-1.17$ & 0.163 \\
\hline Married/stable union & 58 & 43.2 & 76 & 56.7 & 1 & & \\
\hline \multicolumn{8}{|l|}{ Children } \\
\hline Yes & 57 & 46.7 & 65 & 53.2 & 1.90 & $1.12-3.23$ & 0.018 \\
\hline No & 36 & 31.5 & 78 & 68.4 & 1 & & \\
\hline \multicolumn{8}{|l|}{ Persons in the household } \\
\hline$>3$ people & 33 & 41.7 & 46 & 58.2 & 1.16 & $0.67-2.01$ & 0.598 \\
\hline$\leq 3$ persons & 60 & 38.2 & 97 & 61.7 & 1 & & \\
\hline \multicolumn{8}{|l|}{ Training time } \\
\hline$\leq 10$ years & 58 & 37.6 & 96 & 62.3 & 0.81 & $0.47-1.40$ & 0.453 \\
\hline$>10$ years & 35 & 42.6 & 47 & 57.3 & 1 & & \\
\hline \multicolumn{8}{|l|}{ Hypertension } \\
\hline Yes & 8 & 36.3 & 14 & 63.6 & 0.87 & $0.35-2.16$ & 0.759 \\
\hline No & 85 & 39.7 & 129 & 60.2 & 1 & & \\
\hline \multicolumn{8}{|l|}{ Diabetes mellitus } \\
\hline Yes & 7 & 77.7 & 2 & 22.2 & 5.74 & $1.17-28.26$ & 0.032 \\
\hline No & 86 & 37.8 & 141 & 62.1 & 1 & & \\
\hline \multicolumn{8}{|l|}{ City where you work } \\
\hline State Capital & 70 & 42.9 & 93 & 57.0 & 1.64 & $0.91-2.93$ & 0.098 \\
\hline Countryside & 23 & 31.5 & 50 & 68.4 & 1 & & \\
\hline
\end{tabular}




\begin{tabular}{|c|c|c|c|c|c|c|c|}
\hline \multirow{3}{*}{ Variables } & \multicolumn{4}{|c|}{ Test for SARS-CoV-2 } & \multirow{3}{*}{ Odds ratio } & \multirow{3}{*}{$\begin{array}{c}\text { Confidence } \\
\text { interval } \\
95 \%\end{array}$} & \multirow{3}{*}{$\begin{array}{c}p \text { value } \\
\text { (Wald test) }\end{array}$} \\
\hline & \multicolumn{2}{|c|}{ Positive } & \multicolumn{2}{|c|}{ Negative } & & & \\
\hline & $\mathbf{n}$ & $\%$ & $\mathbf{n}$ & $\%$ & & & \\
\hline \multicolumn{8}{|c|}{ Employment relationship } \\
\hline$\geq 2$ jobs & 47 & 46.5 & 54 & 53.4 & 1.68 & $0.99-2.86$ & 0.053 \\
\hline 1 job & 46 & 34.0 & 89 & 65.9 & 1 & & \\
\hline \multicolumn{8}{|l|}{ Workplace } \\
\hline Hospital/UPA & 54 & 45.3 & 65 & 54.6 & 1.66 & $0.98-2.82$ & 0.059 \\
\hline Primary care & 39 & 33.3 & 78 & 66.6 & 1 & & \\
\hline \multicolumn{8}{|l|}{ Sector of work } \\
\hline Inf./ICU/Emergency & 56 & 45.1 & 68 & 54.8 & 1.67 & $0.98-2.83$ & 0.058 \\
\hline Primary Care & 37 & 33.0 & 75 & 66.9 & 1 & & \\
\hline \multicolumn{8}{|c|}{ Use of personal protective equipment } \\
\hline No & 11 & 32.3 & 23 & 67.6 & 0.70 & $0.32-1.51$ & 0.365 \\
\hline Yes & 82 & 40.5 & 120 & 59.4 & 1 & & \\
\hline \multicolumn{8}{|l|}{ Covid-19 care } \\
\hline Yes & 87 & 44.3 & 109 & 55.6 & 4.52 & $1.82-11.26$ & 0.001 \\
\hline No & 6 & 15.0 & 34 & 85.0 & 1 & & \\
\hline
\end{tabular}

UPA - Emergency Care Unit; INF - Infirmary; ICU - Intensive Care Unit.

Table 5 - Factors associated with COVID-19 in nurses, as tested for SARS-CoV-2, after control of confounding variables. Multivariate logistic regression to determine adjusted odds ratio, accuracy, and significance of the estimate, Fortaleza, Ceará, Brazil, 2020

\begin{tabular}{|c|c|c|c|c|}
\hline \multirow{2}{*}{ Variables } & \multirow{2}{*}{$\begin{array}{c}\text { Univariate } \\
\text { analysis } \\
\text { Gross odd } \\
\text { ratio }\end{array}$} & \multicolumn{2}{|c|}{ Multivariate analysis } & \multirow{2}{*}{$\begin{array}{c}p \text { value } \\
\text { (Wald test) }\end{array}$} \\
\hline & & $\begin{array}{l}\text { Adjusted } \\
\text { odds ratio }\end{array}$ & $\begin{array}{c}\text { Confidence } \\
\text { interval 95\% }\end{array}$ & \\
\hline \multicolumn{5}{|l|}{ Children } \\
\hline Yes & 1.90 & 2.11 & $1.19-3.74$ & 0.011 \\
\hline No & 1 & 1 & & \\
\hline \multicolumn{5}{|l|}{ Diabetes disease } \\
\hline Yes & 5.74 & 8.61 & $1.44-51.54$ & 0.018 \\
\hline No & 1 & 1 & & \\
\hline \multicolumn{5}{|l|}{ City where you work } \\
\hline Capital & 1.64 & 1.77 & $0.95-3.32$ & 0.073 \\
\hline Countryside & 1 & 1 & & \\
\hline \multicolumn{5}{|l|}{ Employment links } \\
\hline$\geq 2$ jobs & 1.68 & 1.33 & $0.75-2.36$ & 0.334 \\
\hline 1 job & 1 & 1 & & \\
\hline \multicolumn{5}{|l|}{ Workplace } \\
\hline Hospital/UPA & 1.66 & 1.09 & $0.58-2.05$ & 0.788 \\
\hline Others & 1 & 1 & & \\
\hline \multicolumn{5}{|l|}{ Working sector } \\
\hline Inf./ICU/Emergency & 1.67 & 1.71 & $0.95-3.06$ & 0.073 \\
\hline Others & 1 & 1 & & \\
\hline \multicolumn{5}{|l|}{ Covid-19 care } \\
\hline Yes & 4.52 & 5.71 & $2.15-15.17$ & $<0.001$ \\
\hline No & 1 & 1 & & \\
\hline
\end{tabular}

wave of COVID-19 and new strains. The recommendation is the use quality PPE, have sufficient rest for adequate sleep, avoid overwork, diet, and supplements for proper nutrition and increased immunity, aimed at reducing the chances of infection ${ }^{(16)}$.

The study also shows that nurses need resilience, support from the employer, staff, and the attendees through actions and resources. Recognition actions that are carried out in Europe aim to keep the spirits up, and nurses are moved by the recognition of gratitude and donations so that their work is performed safely. Nurses need to feel that their needs are met, that their leaders and institutions care for them, and that they wear appropriate PPE as the pandemic spreads. Resilience should not be seen as only individual responsibility but also collective and organizational ${ }^{(17)}$.

However, strict biosecurity measures can be stressful for healthcare professionals ${ }^{(18)}$. Research pointed out the most common discomforts among nurses who wear PPE are sweating when wearing surgical masks (50.9\%) or N95 (64.2\%), dry hands by constant washing and wearing gloves (73.9\%), sweating when wearing overalls/aprons (84.1\%), vision problems and headache when wearing goggles/ face protectors (47.9\%). There was a relationship between more than four hours of PPE use and the occurrence of redness on the face, nasal bridge and ears, dry mouth, dry hands, headache, and sweating. The availability and safety of PPE are crucial for the protection of nurses, so research is needed to examine the quality and effectiveness of these materials to keep the workforce healthy in the pandemic ${ }^{(19)}$.

The prevalence of testing for SARS-CoV-2 and COVID-19 in nurses was, respectively, $63.3 \%$ and $25 \%$, mainly using serology. Therefore, a systematic review with meta-analysis identified that the tests most performed among health professionals were serology and RT-PCR. However, the rate of screening and infection by SARS-CoV-2 were lower than those in the present study, 
being, respectively, $11 \%$ and $7 \%^{(12)}$. Other studies with health professionals identified COVID-19 prevalence of $4.04 \%{ }^{(20)}$ e $6 \%{ }^{(21)}$.

The higher the exposure to the virus, the higher the likelihood of infection and the consequences are changes in schedule and work overload ${ }^{(20)}$. Research shows that these professionals have more stress, work overload, fatigue, and fear ${ }^{(7,18)}$. PPE is essential for these professionals. Another study showed that the detection of antibodies to SARS-CoV-2 was lower in health professionals who used face coverings in care compared to those who did not use it. However, the shortage of PPE is a usual report, especially of $\mathrm{N} 95$ masks ${ }^{(21)}$. Few studies include only nurses, but most of the surveys with health professionals show that those most affected by COVID-19 are nurses ${ }^{(12)}$. As for the work sector, the majority of those affected worked in infirmaries, having a significantly higher seroprevalence than the frontline professionals, perhaps because they used fewer PPE at work ${ }^{(12,20)}$.

The most common COVID-19 symptoms were anosmia, ageusia, and myalgia, agreeing with other studies ${ }^{(12,21)}$. The research observed that the infection is more frequent in those who work in cities with a high incidence of COVID-19 in the general population ${ }^{(21)}$. It emphasizes the importance of expanding testing for health professionals to maintain adequate human resources and reduce the risk of transmission to vulnerable patients ${ }^{(22)}$. In the univariate logistic regression, nurses with children, people with diabetes, workers in the capital, with two or more jobs, in a hospital or emergency room, in an infirmary, intensive care or emergency, and who treated patients with COVID-19 had more chances of infection. In the multivariate analysis, only having children, being diabetic, and providing direct care to patients with COVID-19 were factors associated with infection.

The research did not identify other studies on whether having children is a risk factor for COVID-19. However, it is assumed that these nurses, in addition to viral contact at work, have a more expanded community contact network or more jobs and, therefore, more exposure to the virus. For other diseases, such as human immunodeficiency virus infection, studies show that married people can have better health care due to the support of their partner and children when they assist in therapeutic treatment; but if there are children or dependent family members, there will be a division of the time available to take care of themselves and others ${ }^{(23-24)}$.

All the nurses lived with other people, and most had children. These professionals are afraid to transmit the infection to family members ${ }^{(7)}$. A systematic review with meta-analysis suggested the possibility of transmission of the new coronavirus even by asymptomatic individuals ${ }^{(12,25)}$, and health professionals have a high risk of infection for extensive contact with patients. Research pointed out that the principal way of transmission perceived by health professionals was not to use PPE consistently in the care of patients with COVID-19, in addition to contact with infected at home and community ${ }^{(26)}$.

A systematic review showed that among health professionals facing pandemics, the fear of becoming infected or infecting family members was at the forefront of the mental challenges they face, and female nurses conferred greater risk. Stigmatization by family members/society may have negative implications, generate stress and isolation. For all this, coping strategies and psychosocial support are necessary according to sociocultural environments, which, depending on the geographical location and incidence of COVID-19, can be contrasting ${ }^{(27)}$.

Research shows that the most prevalent comorbidities in patients with COVID-19 are hypertension, diabetes mellitus, cardiovascular diseases, and chronic obstructive pulmonary disease, and are the risk factors for disease progression and unfavorable outcomes $^{(28-29)}$. To date, there are no studies that demonstrate the independent predictive value of diabetes in COVID-19 mortality. However, there is speculation of an association between increased susceptibility to the virus and disease progression ${ }^{(29)}$. There seems to be a tropism of the virus by beta pancreatic cells, which can contribute to a worse glycemic control, with a negative impact for people with diabetes and for those who do not present this comorbidity before the diagnosis of COVID-19(30).

Given the above, considering that vaccination and new circulating strains are still incipient in Brazil, the need to follow biosecurity measures by nurses and other health professionals, as well as the use of masks, hand washing, gel alcohol, and social distancing for the general population and health professionals when they are not in service is emphasized ${ }^{(21,26)}$.

\section{Study limitations}

A limitation of the study was that the nurses were not personally accessible due to the control measures of COVID-19 transmission in health institutions. Furthermore, due to the nature of the data collection technique, we do not know the circumstances under which nurses answered the questionnaire amidst their intense routine during the pandemic.

\section{Contributions to the fields of Nursing, Health and Public Policy}

The findings of the study point to the need for measures to support nurses during the pandemic, both within the institutions and public and labor policies. Aspects that can be considered are expanded testing for SARS-CoV-2, provision of PPE in adequate quantity and quality, ongoing in-service education, and better working conditions. Therefore, this study will be disseminated in academia and other competent bodies. We emphasize the importance of future research to evaluate measures that can improve and facilitate the work of nurses in the context of pandemics.

\section{CONCLUSION}

The prevalence of testing for SARS-CoV-2 was $63.3 \%$, and COVID-19 was $25.0 \%$, highlighting the symptoms of anosmia, ageusia, and myalgia. In the univariate logistic regression, nurses with children, people with diabetes, workers in the capital, with two or more jobs, in a hospital or emergency room, infirmary, ICU, or emergency room, and working on the frontline of the fight against the pandemic had more chances for COVID-19. Multivariate logistic regression analysis confirmed that only nurses with children, people with diabetes, and working in the frontline had more possibilities for COVID-19. 


\section{REFERENCES}

1. Madabhavi I, Sarkar M, Kadakol N. COVID-19: a review. Monaldi Arch Chest Dis. 2020;90(2):248-58. https://doi.org/10.4081/ monaldi.2020.1298

2. Ministério da Saúde (BR). Boletim Epidemiológico Especial. Doença pelo COVID-19 [Internet]. 2021 [cited 2021 Jan 20]. Available from: https://www.gov.br/saude/pt-br/media/pdf/2021/janeiro/15/boletim_epidemiologico_covid_45.pdf

3. Governo do Estado do Ceará. Boletim Epidemiológico. Doença pelo COVID-19[Internet]. 2021. [cited 2021 Jan 20]. Available from: https:// www.saude.ce.gov.br/wp-content/uploads/sites/9/2020/02/boletim_covid_n01_20211501.pdf

4. Dourado I, Magno L, Soares F, Massa P, Nunn A, Dalal S, et al. Adapting to the COVID-19 pandemic: continuing HIV prevention services for adolescents through telemonitoring, Brazil. AIDS Behav. 2020;24(7):1994-9. https://doi.org/10.1007/s10461-020-02927-w

5. Huang L, Lin G, Tang L, Yu L, Zhou Z. Special attention to nurses' protection during the COVID-19 epidemic. Crit Care. 2020;24(1):120. https:// doi.org/10.1186/s13054-020-2841-7

6. Lai J, Ma S, Wang Y, Cai Z, Hu J, Wei N, et al. Factors associated with mental health outcomes among health care workers exposed to coronavirus disease 2019. JAMA Netw Open 2020;3(3):e203976. https://doi.org/10.1001/jamanetworkopen.2020.3976

7. Shen X, Zou X, Zhong X, Yan J, Li L. Psychological stress of ICU nurses in the time of COVID-19. Crit Care. 2020;24(1):200. https://doi. org/10.1186/s13054-020-02926-2

8. Mo Y, Deng L, Zhang L, Lang Q, Liao C, Wang N, et al. Work stress among Chinese nurses to support Wuhan in fighting against COVID-19 epidemic. J Nurs Manag. 2020;28(5):1002-9. https://doi.org/10.1111/jonm.13014

9. Von Elm E, Altman DG, Egger M, Pocock SJ, Gotzsche PC, Vandenbroucke JP, et al. The strengthening the reporting of observational studies in epidemiology (STROBE) statement: guidelines for reporting observational studies. Int J Surg. 2014;12(12):1495-9. https://doi. org/10.1016/j.ijsu.2014.07.013

10. Conselho Federal de Enfermagem (Cofen). Enfermagem em Números [Internet]. 2020 [cited 2020 May 10]. Available from: http://www. cofen.gov.br/enfermagem-em-numeros

11. Bandyopadhyay S, Baticulon RE, Kadhum M, Alser M, Ojuka DK, Badereddin Y, et al. Infection and mortality of healthcare workers worldwide from COVID-19: a systematic review. BMJ Glob Health. 2020;5(12):e003097. https://doi.org/10.1136/bmjgh-2020-003097

12. Gómez-Ochoa SA, Franco OH, Rojas LZ, Raguindin PF, Roa-Díaz ZM, Wyssmann BM, et al. COVID-19 in health-care workers: a living systematic review and meta-analysis of prevalence, risk factors, clinical characteristics, and outcomes. Am J Epidemiol. 2021;190(1):161-75. https://doi.org/10.1093/aje/kwaa191

13. Wong LY, Tan AL, Leo Y, Lee VJM, Toh MPHS. Healthcare workers in Singapore infected with COVID-19: 23 January-17 April 2020. Influenza Other Respir Viruses. 2020;15:218-26. https://doi.org/10.1111/irv.12803

14. Asfahan S, Deokar K, Dutt N, Niwas R, Jain P, Agarwal M. Extrapolation of mortality in COVID-19: exploring the role of age, sex, comorbidities and health-care related occupation. Monaldi Arch Chest Dis. 2020;90(2):313-7 https://doi.org/10.4081/monaldi.2020.1325

15. Zhang $M$, Zhou M, Tang F, Wang $Y$, Nie H, Zhang L, et al. Knowledge, attitude, and practice regarding COVID-19 among healthcare workers in Henan, China. J Hosp Infect. 2020;105(2):183-7. https://doi.org/10.1016/j.jhin.2020.04.012

16. Zheng L, Wang X, Zhou C, Liu Q, Li S, Sun Q, et al. Analysis of the infection status of healthcare workers in Wuhan during the COVID-19 outbreak: a cross-sectional study. Clin Infect Dis. 2020;71(16):2109-13. https://doi.org/10.1093/cid/ciaa588

17. Maben J, Bridges J. Covid-19: supporting nurses' psychological and mental health. J Clin Nurs. 2020;29(15-16):2742-50. https://doi. org/10.1111/jocn.15307

18. Said RM, El-Shafei DA. Occupational stress, job satisfaction, and intent to leave: nurses working on front lines during COVID-19 pandemic in Zagazig City, Egypt. Environ Sci Pollut Res Int. 2021;28(7):8791-8801. https://doi.org/10.1007/s11356-020-11235-8

19. Atay $S$, Cura SÜ. Problems encountered by nurses due to the use of personal protective equipment during the coronavirus pandemic: results of a survey. Wound Manag Prev. 2020;66(10):12-6. https://doi.org/10.25270/wmp.2020.10.1216

20. Iversen K, Bundgaard H, Hasselbalch RB, Kristensen JH, Nielsen PB, Pries-Heje M, et al. Risk of COVID-19 in health-care workers in Denmark: an observational cohort study. Lancet Infect Dis. 2020;20(12):1401-8. https://doi.org/10.1016/S1473-3099(20)30589-2

21. Self WH, Tenforde MW, Stubblefield WB, Feldstein LR, Steingrub JS, Shapiro NI, et al. Seroprevalence of SARS-CoV-2 among frontline health care personnel in a multistate hospital network - 13 academic medical centers, April-June 2020. MMWR Morb Mortal Wkly Rep. 2020;69(35):1221-6. https://doi.org/10.15585/mmwr.mm6935e2

22. Keeley AJ, Evans C, Colton H, Ankcorn M, Cope A, State A, et al. Roll-out of SARS-CoV-2 testing for healthcare workers at a large NHS foundation trust in the United Kingdom, March 2020. Euro Surveill. 2020;25(14):2000433. https://doi.org/10.2807/1560-7917. ES.2020.25.14.2000433

23. Lenzi L, Tonin FS, Souza VR, Pontarolo R. Social support and HIV: Relationship between clinical and sociodemographic characteristics and treatment adherence. Psicol: Teor Pesqui. 2018;34:e34422. https://doi.org/10.1590/0102.3772e34422 
24. Hipólito RL, Oliveira DC, Costa TLD, Marques SC, Pereira ER, Gomes AMT. Quality of life of people living with HIV/AIDS: temporal, sociodemographic and perceived health relationship. Rev Latino-Am Enfermagem. 2017;25:e2874. https://doi.org/10.1590/1518-8345.1258.2874

25. Asselah T, Durantel D, Pasmant E, Lau G, Schinazi RF. COVID-19: discovery, diagnostics and drug development. J Hepatol. 2021;74(1):168-84. https://doi.org/10.1016/j.jhep.2020.09.031

26. Jin YH, Huang Q, Wang YY, Zeng XT, Luo LS, Pan ZY, et al. Perceived infection transmission routes, infection control practices, psychosocial changes, and management of COVID-19 infected healthcare workers in a tertiary acute care hospital in Wuhan: a cross-sectional survey. Mil Med Res. 2020;7(1):24. https://doi.org/10.1186/s40779-020-00254-8

27. Stuijfzand S, Deforges C, Sandoz V, Sajin CT, Jaques C, Elmers J, et al. Psychological impact of an epidemic/pandemic on the mental health of healthcare professionals: a rapid review. BMC Public Health. 2020;20(1):1230. https://doi.org/10.1186/s12889-020-09322-z

28. Abdi A, Jalilian M, Sarbarzeh PA, Vlaisavljevic, Z. Diabetes and COVID-19: a systematic review on the current evidences. Diabetes Res Clin Pract. 2020;166:108347. https://doi.org/10.1016/j.diabres.2020.108347

29. Tadic M, Cuspidi C, Sala C. COVID-19 and diabetes: is there enough evidence? J Clin Hypertens (Greenwich). 2020;22(6):943-8. https://doi. org/10.1111/jch.13912

30. Apicella M, Campopiano MC, Mantuano M, Mazoni L, Coppelli A, Del Prato S. COVID-19 in people with diabetes: understanding the reasons for worse outcomes. Lancet Diabetes Endocrinol. 2020;8(9):782-92. https://doi.org/10.1016/S2213-8587(20)30238-2 